\title{
Late Jurassic reef bioerosion - the dawning of a new era
}

\author{
MARKUS BERTLING
}

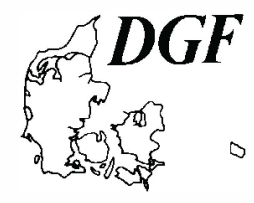

Bertling, M.: Late Jurassic reef bioerosion - the dawning of a new era. Bulletin of the Geological Society of Denmark, Vol. 45, pp. 173-176. Copenhagen 1999-01-30. https://doi.org/10.37570/bgsd-1998-45-24

Coral reefs of the Late Jurassic (Oxfordian) in northern Germany and France have a style of bioerosion that is closer to that of Late Triassic reefs than of modern ones. Boring sponges played minor roles here but gradually became more important in more southerly regions during the Tithonian. This is likely to be linked to a falling sea-level whose increased nutrient input triggered microbial growth in shallow water. With sponges feeding on microbes, the Late Jurassic was the time of a change to modern borer associations in reefs.

Key words: Bioerosion, reefs, Jurassic, nutrients, sponges.

M. Bertling [markus.bertling@uni-muenster.de], Geologisch-Paläontologisches Museum, Pferdegasse 3, D - 48143 Münster, Germany. 1 September 1998.

The bioerosion of modern reefs is characterised by the prevalent action of grazing sea urchins and fishes; clionid sponges generally are the most important macroborers, with lithophagine bivalves and micropolychaetes being locally abundant (e.g. Hutchings 1986). Neither Lithophaginae nor sponges of the family Clionidae (or related forms) have been reported from reefs older than Late Triassic age (own observations); and grazing reef fish families only originated in the Eocene (Bellwood 1996). This implies that preCenozoic and moreover pre-Jurassic reef bioerosion must have significantly differed from the modern situation at least regarding its producers and thus control factors as well. When and how the change occurred so far has remained largely obscure.

Preliminary studies suggest a paramount increase in bivalve boring within the Late Triassic but no major changes from Late Cretaceous to Oligocene; sponges have significantly contributed to reef bioerosion at least from the mid-Cretaceous onwards. This group therefore has become important sometime during the Jurassic; reef-building, however, occurred mainly in the Late Jurassic.

\section{Study sites}

The localities reported on here are Oxfordian (Late Jurassic) in age. Their stratigraphy, position (northern Germany and northern Paris Basin) and palaeoen- vironment has been documented before (Bertling 1993; Bertling \& Insalaco 1998). The study sites (Fig. 1) are similar in depth $(0-20 \mathrm{~m})$ as well as climatic, nutrient and salinity conditions but represent various environments regarding water energy and sedimentation (including turbidity): a high-energy coral-microbial reef (Novion-Porcien NP), an occurrence within permanently turbulent water with slight intermittent (storm) sedimentation (Luchsholklippe LU), a deepwater biostrome at the storm-wave base with relatively high sedimentation rate (Arensberg AR), and a beach deposit with hardly any siliciclastic influx (Mönkeberg HA).

\section{Methods}

Samples of reef corals were collected in the outcrops irrespective of taxonomy, size and intensity of bioerosion.After cleaning the surfaces either with plain water or hydrogen peroxide, the area of visible colony surfaces was measured. Borings were identified by their typical apertures in most cases; only at Novion-Porcien the dissolution of the coral skeleton facilitated threedimensional investigation. The mean of boring apertures per square centimetre of coral colony surface was multiplied by the same factor to give the diameter of the circles in Figure 2. Body fossils of the tracemakers (bivalves) have not been included due to their rarity. 


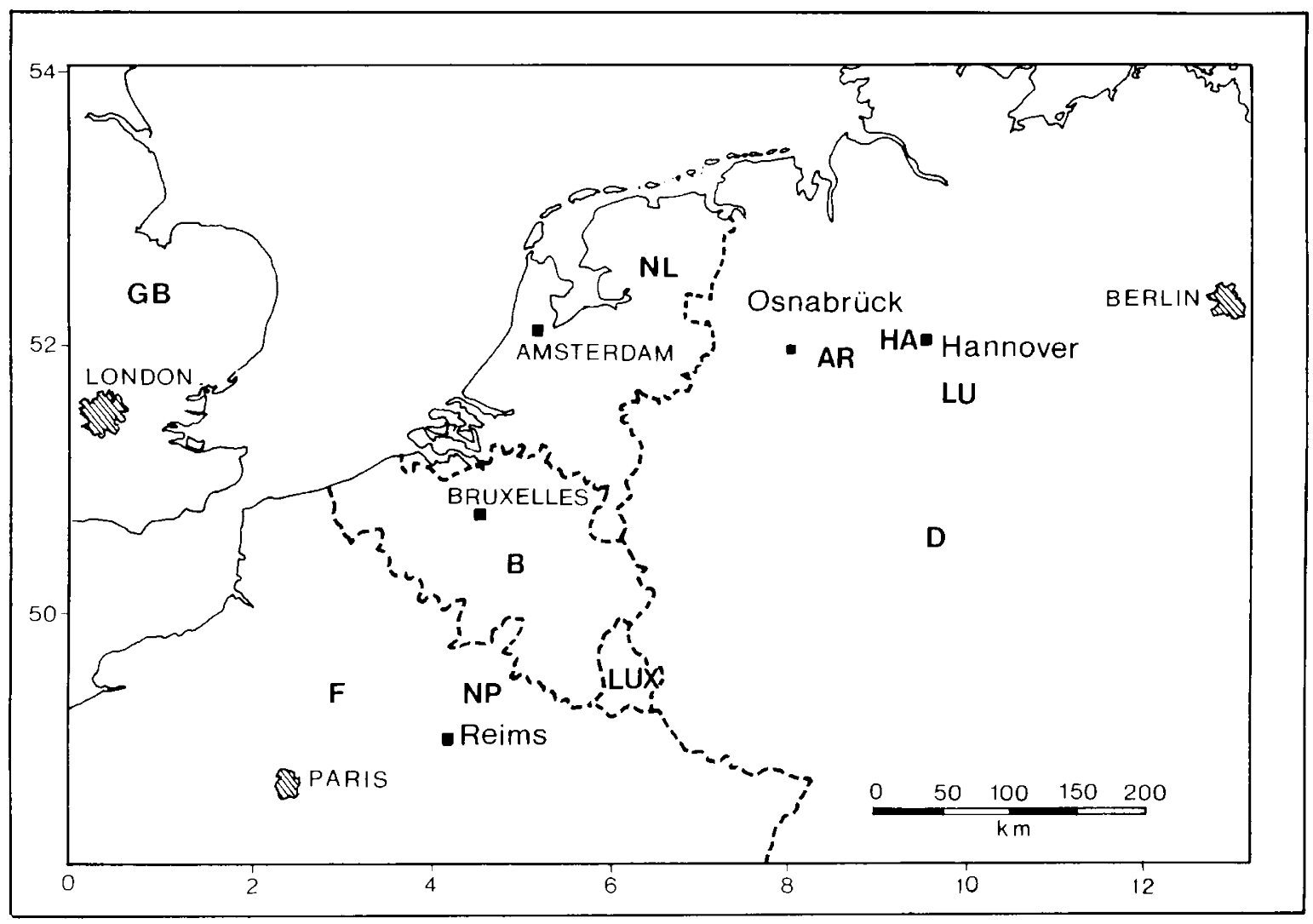

Fig. 1. Study sites: abbreviations: northern France, $\mathrm{NP}=$ Novion-Porcien; northern Germany, $\mathrm{AR}=$ Arensberg, $\mathrm{HA}=$ Mönkeberg/Hannover and LU = Luchsholklippe/Osterwald. Numbers on the margins indicate longitude and latitude.

\section{Results}

No locality showed traces of grazing although, e.g., spines of cidaroid sea urchins are ubiquitous. In general, bioerosion therefore is identical to (macro-) boring in the reefs studied. Its intensity is highly variable, however (Fig. 2) and appears to have mostly been controlled by the intensity of sedimentation.

The boring fauna is characterized by high percentages of bivalves (mostly Lithophaginae and Gastrochaenidae) and "worms" ("Vermes", mostly spionid polychaetes and sipunculans); other groups such as phoronids, cirripedia, foraminifera, or bryozoans occur very subordinately. Which factor(s) control the prevalence of bivalves or "worms" may only be speculated about: perhaps "worms" comprise mostly polychaetes at one locality and mostly sipunculans at an other, or "worms" tolerate sedimentation better. In any case it has been observed that most borings have perforated the corals postmortally, i.e. their producers were dead-coral borers. The specimens studied suggest that only Gastrochaenidae had developed the ability to bore into living coral substrate by the Late Jurassic. It is not clear, however, whether their spat could penetrate living polyps.
In general, most localities exhibit a boring pattern similar to Late Triassic occurrences with regard to the spectrum of producers. However, Novion-Porcien differs from the other Oxfordian localities by its dominance of sponges which gives it a "modern" aspect. Sponges were very rare though present elsewhere, a fact that may hardly be explained biogeographically. Considering this phenomenon, the report of a Bajocian (Middle Jurassic) coral-microbial reef having suffered intense sponge bioerosion from Morocco (Warme 1977) is remarkable.

Microbial reefs grew under very low sedimentation rate and may tolerate low oxygen and raised nutrient levels (Leinfelder et al. 1993). Modern Clionidae are adapted to very much the same conditions regarding oxygenation (K. Holmes, pers. comm. 1996) and nutrient supply, moreover they feed mostly on bacteria (Rose \& Risk 1985). This means that Jurassic boring sponges could only thrive in limited environments and were triggered especially by presence of their main source of nutrition, i.e. bacteria suspended from microbial mats. This also readily explains why Clionidae are found in latest Jurassic (Tithonian) reefs abundantly, quite different from the Oxfordian situation: the Tithonian was a time of global sea-level fall (e.g., 


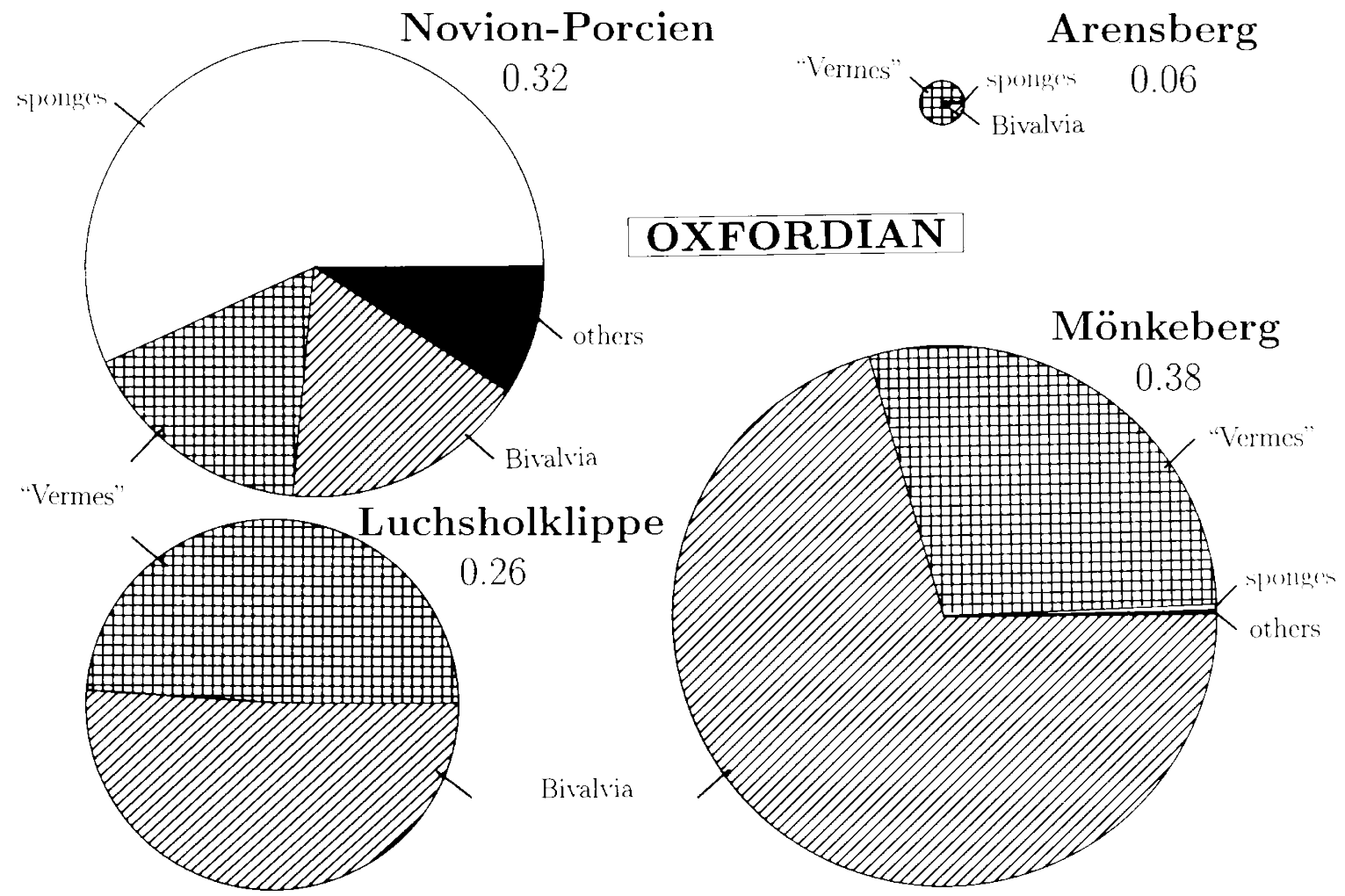

Fig. 2. Producers of macroborings in Oxfordian reef corals; numbers below locality names give mean of boring apertures per $\mathrm{cm}^{2}$ colony surface, diametres of circles vary accordingly.

Hallam 1988) with increased nutrient flux onto the shelves from exposed lowlands, which in turn resulted in higher productivity, higher biomass turnover rates and thus raised importance of decomposing bacteria. Once established as abundant and ubiquitous reef borers, clionids could maintain and strengthen their position until today, owing to rapid growth and the ability to colonize living corals (see e.g., Highsmith 1981, Bromley 1978).

The Late Jurassic thus was the time of gradual change within borer associations, paving the way for the high levels and the taxonomic composition of modern bioerosion by the emplacement of boring sponges.

\section{Dansk sammendrag}

Sen jurassiske (Oxfordien) koralrev i Nordtyskland og Frankrig har en type bioerosion, der er mere lig den $i$ den sen triassiske rev end $i$ de moderne. Borende spongier spillede en mindre rolle, men blev gradvis mere vigtig i mere sydlige regioner i løbet af Tithonien. Dette kan sandsynligvis kædes sammen med faldende havniveau, som med stigende indhold af næring udløste mikrobe-vækst i lavt vand. Med spongier ernærende sig af mikrober blev sen Jura tiden for et skift til moderne borende selskaber i rev.

\section{References}

Bellwood, D. R. 1996: The Eocene fishes of Monte Bolca: the earliest coralreef fish assemblage. Coral Reefs 15, 11-19.

Bertling, M. 1993: Ecology and distribution of the Late Jurassic Scleractinian Thamnasteria concinna (Goldfuss) in Europe. Palaeogeography, Palaeoclimatology, Palaeoecology 105, 311-335.

Bertling, M. \& Insalaco, E. 1998: Late Jurassic microbialcoral reefs from the northern Paris Basin - facies, palaeoecology and palaeobiogeography. Palaeogeography, Palaeoclimatolology, Palaeoecology 139, 139-175.

Bromley, R. G. 1978: Bioerosion of Bermuda reefs. Palaeogeography, Palaeoclimatolology, Palaeoecology 23, 169-197.

Hallam, A. 1988: A reevaluation of Jurassic eustasy in the light of new data and the revised Exxon curve. In Wilgus, B. H., Hastings, B. S., Kendall, B. G. S., Posamentier, H. W., Ross, C. A. \& van Wagoner, J. C. (eds) Sea-level 
changes: an integrated approach. SEPM Special Publications 42, 261-273.

Highsmith, R. C. 1981: Coral bioerosion at Enewetak agents and dynamics. Internationale Revue der gesamten Hydrobiologie 66, 335-375.

Hutchings, P. A. 1986: Biological destruction of coral reefs - a review. Coral Reefs 4, 239-252.

Leinfelder, R. R., Nose, M., Schmid, D. U. \& Werner, W. 1993: Microbial crusts of the Late Jurassic: composition, palaeoecological significance and importance in reef construction. Facies 29, 195-229.

Rose, C. S. \& Risk, M. J. 1985: Increase in Cliona deletrix infestation of Montastrea cavernosa heads on an organically polluted portion of the Grand Cayman fringing reef. Marine Ecology 6, 345-363.

Warme, J. E. 1977: Carbonate borers - their role in reef ecology and preservation. American Association of Petroleum Geologists Studies in Geology 4, 261-279. 